\title{
Reaction Analysis of Ethanol Electro-Oxidation on PdRu/C Catalyst at Intermediate Temperature
}

\author{
Iori Shimada ${ }^{1}$, Yoshito Oshima ${ }^{2}$ and Junichiro Oтомо ${ }^{2}$ \\ ${ }^{1} \mathcal{M a t e r i a l s}$ and Chemical Engineering Course, Faculty of Textile Science and Technology, \\ Shinshu University, 3-15-1 Tokida, Ueda-shi, Nagano 386-8567, Japan \\ ${ }^{2}$ Department of Environment Systems, Graduate School of Frontier Sciences, The University of Tokyo, \\ 5-1-5 Kashiwanoha, Kashiwa-shi, Chiba 277-8563, Japan
}

Keywords: Direct Ethanol Fuel Cell, Intermediate Temperature, Non-Pt Catalyst, PdRu/C, Anode

To evaluate the availability of non-Pt catalysts in a direct ethanol fuel cell operating at an intermediate temperature, a $\mathrm{PdRu} / \mathrm{C}$ catalyst was synthesized by a liquid phase reduction method and its catalytic activity for ethanol electrooxidation was investigated at approximately $250^{\circ} \mathrm{C}$ using a single cell fabricated with $\mathrm{CsH}_{2} \mathrm{PO}_{4}$ proton-conducting solid electrolyte. Electrochemical measurement and reaction product analysis revealed that direct electro-oxidation of etha$\mathrm{nol}$ and hydrogen production from ethanol proceeded in parallel on $\mathrm{PdRu} / \mathrm{C}$. The $\mathrm{PdRu} / \mathrm{C}$ catalyst showed high activity for hydrogen production reaction comparable to that on the $\mathrm{PtRu} / \mathrm{C}$ catalyst, which results in high current density at low electrode potentials $(<200 \mathrm{mV}$ ). C-C bond dissociation proceeded rapidly on the $\mathrm{PdRu} / \mathrm{C}$ catalyst, while the subsequent oxidation of the adsorbed $C_{1}$ species may be the rate-determining step at the intermediate temperature. For further activation of the $\mathrm{PdRu} / \mathrm{C}$ catalyst, activation of surface $\mathrm{OH}$ should be investigated.

\section{Introduction}

Direct ethanol fuel cells (DEFCs) have a high theoretical energy conversion efficiency and are promising power sources for automotive and portable applications. DEFCs also have several advantages over fuel cells with hydrogen fuel, such as ease of handling, storage, and transportation of liquid fuel, high energy density, and compactness of systems without a reformer.

Despite great efforts and numerous studies, however, DEFCs operating at low temperatures $\left(<100^{\circ} \mathrm{C}\right)$ suffer from the slow kinetics of ethanol oxidation (Lamy et al., 2001). It has been reported that the $\mathrm{C}-\mathrm{C}$ bond dissociation of ethanol hardly proceeded on a Pt catalyst and the main reaction products were acetaldehyde and acetic acid (Wang et al., 2006b). Therefore, the total oxidation reaction of ethanol does not occur and an efficient use of ethanol fuel has not been accomplished.

In the previous studies, we have investigated the ethanol electro-oxidation on Pt-based catalysts at an intermediate temperature (approximately $250^{\circ} \mathrm{C}$ ) using protonconducting solid electrolyte, cesium dihydrogen phosphate $\left(\mathrm{CsH}_{2} \mathrm{PO}_{4}\right)$ (Otomo et al., 2008a, 2008b; Shimada et al., 2011, 2013). $\mathrm{CsH}_{2} \mathrm{PO}_{4}$ exhibits a superprotonic phase transition at ca. $230^{\circ} \mathrm{C}$, leading to a stable highly conducting phase $\left(>10^{-2} \mathrm{Scm}^{-1}\right)$ under an appropriate amount of hu-

Received on November 13, 2013; accepted on January 5, 2014 DOI: $10.1252 /$ jcej. 13 we296

Correspondence concerning this article should be addressed to J. Otomo (E-mail address: otomo@k.u-tokyo.ac.jp).

Presented at International Symposium on Innovative Materials for Processes in Energy Systems 2013 (IMPRES2013) at Fukuoka, Japan. midity (Otomo et al., 2003). From an electrochemical measurement and reaction product analysis of ethanol electrooxidation at approximately $250^{\circ} \mathrm{C}$, we have obtained the following results (Shimada et al., 2011): (i) activation overpotential decreased drastically; (ii) $\mathrm{C}-\mathrm{C}$ bond dissociation proceeded rapidly; and (iii) the main reaction product was $\mathrm{CO}_{2}$. Although $\mathrm{CH}_{4}$ was produced as a by-product on the $\mathrm{Pt} / \mathrm{C}$ catalyst, it was suppressed with $\mathrm{Ru}$ addition to the $\mathrm{Pt} / \mathrm{C}$ catalyst (i.e., $\mathrm{PtRu} / \mathrm{C}$ catalyst), which suggests that activation of $\mathrm{OH}$ species on the catalyst surface is effective in accelerating the total oxidation of ethanol at the intermediate temperature (Shimada et al., 2013). These results indicate a possibility for the efficient use of ethanol fuel with the DEFC being operated at the intermediate temperature.

Because the Pt-based catalysts, however, lead to high materials cost for DEFCs, the development of alternatives is expected. In this study, we investigated the availability of non-Pt catalysts for the DEFCs operated at the intermediate temperature. According to the investigation on the Pt-based catalysts mentioned above, the catalytic activities required for the total oxidation of ethanol are as follows: (i) C-C bond dissociation; (ii) water adsorption and the subsequent dissociation; and (iii) a charge-transfer reaction. In light of these indexes, we focused on Pd and $\mathrm{Ru}$. In the literature, it is reported that (i) turnover frequencies for $\mathrm{C}-\mathrm{C}$ bond dissociation of ethanol on Pd are approximately half as high as those on Pt (Ferrin et al., 2009); (ii) exchange current density of the $\mathrm{H}_{2}$ electro-oxidation reaction on Pd is comparable with that on Pt (Nørskov et al., 2005); (iii) Ru exhibits a relatively high catalytic activity toward the water adsorption and dissociation reaction (Wang et al., 2006a); and (iv) addition of $\mathrm{Ru}$ to an electrode catalyst promotes the activity of surface $\mathrm{OH}$ and accelerates the oxidation of surface car- 
bon species, which is known as the bifunctional mechanism (Watanabe and Motoo, 1975). Hence, we combined Pd and $\mathrm{Ru}$ for satisfying the three indexes of catalytic activities required for the total oxidation of ethanol mentioned earlier. Therefore, in this study, we synthesized the $\mathrm{PdRu} / \mathrm{C}$ catalyst and investigated its catalytic activity for ethanol electro-oxidation at the intermediate temperature. We also discussed the reaction mechanism of ethanol electro-oxidation on the $\mathrm{PdRu} / \mathrm{C}$ catalyst and compared it with that on the Pt-based catalysts.

\section{Experimental}

\subsection{Synthesis of PdRu/C catalyst}

A carbon-supported palladium ruthenium catalyst $(\mathrm{PdRu} / \mathrm{C} ; 20 \mathrm{wt} \% \mathrm{Pd}$ and $20 \mathrm{wt} \% \mathrm{Ru})$ was prepared by a liquid phase reduction method using $\mathrm{NaBH}_{4}$ (Wako Pure Chemical Industries, Ltd.) as a reducing agent. $\mathrm{Pd}\left(\mathrm{NO}_{3}\right)_{2}$ (Kanto Chemical Co., Inc.) was dissolved in $1 \mathrm{M} \mathrm{HCl}$ to form a yellow solution with $0.005 \mathrm{M} \mathrm{Pd}^{2+}$. An ammonia solution $(28 \%, \mathrm{v} / \mathrm{v})$ was added dropwise until the yellow solution became colorless, which indicates the formation of the $\left[\mathrm{Pd}\left(\mathrm{NH}_{3}\right)_{4}\right]^{2+}$ complex (Cheng et al., 2010). A calculated amount of $\mathrm{Ru}(\mathrm{NO})\left(\mathrm{NO}_{3}\right)_{3}$ (Strem Chemicals, Inc.) was added to the solution, and the $\mathrm{pH}$ value was adjusted to 10 with $1 \mathrm{M} \mathrm{NaOH}$. An appropriate amount of a carbon support (Ketjen black, Lion Co.) was added and dispersed ultrasonically for $1 \mathrm{~h}$. The suspension was reduced by the dropwise addition of $1 \mathrm{M} \mathrm{NaBH}_{4}$ solution (the molar ratio of metal ion and $\mathrm{NaBH}_{4}$ was $1: 13$ ) at $80^{\circ} \mathrm{C}$ under a mechanically stirred condition. After filtration, washing, and drying, the catalyst was heat-treated at $350^{\circ} \mathrm{C}$ in a reductive atmosphere of $1 \% \mathrm{H}_{2} / 99 \%$ Ar for $2 \mathrm{~h}$.

The synthesized catalyst was characterized with X-ray diffraction (XRD) and transmission electron microscopy (TEM). The XRD patterns were recorded using a SmartLab $\mathrm{X}$-ray diffractometer (Rigaku Co.) with $\mathrm{CuK \alpha}$ radiation at $40 \mathrm{kV}$ and $20 \mathrm{~mA}$. TEM investigation was carried out by a JEM-2100 microscope (JEOL Ltd.) operated at $200 \mathrm{kV}$.

\subsection{Preparation of membrane electrode assembly}

The fabrication procedure of a membrane electrode assembly (MEA) is described in our previous study (Shimada et al., 2011). The composite of $\mathrm{CsH}_{2} \mathrm{PO}_{4}$ (Soekawa Chemical Co., Ltd.) and $\mathrm{SiO}_{2}$ (Nippon Silica Industrial Co., Ltd.) was prepared by an evaporation-to-dryness method (Shigeoka et al., 2004). To enhance the mechanical stability of the electrolyte, $1 \mathrm{wt} \%$ of $\mathrm{SiO}_{2}$ was introduced. The obtained composite powder was pressed at $4 \mathrm{tcm}^{-2}$ to form a solid electrolyte disk (diameter: $20 \mathrm{~mm}$, thickness: ca. $1 \mathrm{~mm}$ ). The synthesized $\mathrm{PdRu} / \mathrm{C}$ catalyst was used for preparing a working electrode, while a commercial carbon-supported platinum catalyst (Pt/C; Pt: 46wt\%, Tanaka Kikinzoku Kogyo $\mathrm{KK}$ ) was used for fabricating the counter and reference electrodes. An ultrasonically dispersed mixture of the catalyst powder, polytetrafluoroethylene, and water was first spread on a carbon paper (Toray Industries, Inc.) and then heated in $1 \% \mathrm{H}_{2} / 99 \% \mathrm{Ar}$ at $350^{\circ} \mathrm{C}$ for $2 \mathrm{~h}$. A saturated $\mathrm{CsH}_{2} \mathrm{PO}_{4}$ solution was infiltrated into the electrodes and then they were attached to the electrolyte disk by hot pressing at $150^{\circ} \mathrm{C}$ and $1 \mathrm{~kg} \mathrm{~cm}^{-2}$. The reference electrode was attached to the counter-electrode side. The geometric electrode area was $0.57 \mathrm{~cm}^{2}$ for the working and counter electrodes and $0.12 \mathrm{~cm}^{2}$ for the reference electrode. Metal loadings on all electrodes were $2 \mathrm{mg} \mathrm{cm}^{-2}$.

\subsection{Electrochemical measurement and reaction product analysis}

The MEA was set between two Pyrex glass tubes, placed in a thermostatic chamber. A gaseous mixture of ethanol (Kanto Chemical Co., Inc.), water, and argon (typical molar ratio $\mathrm{C}_{2} \mathrm{H}_{5} \mathrm{OH}: \mathrm{H}_{2} \mathrm{O}: \mathrm{Ar}=13: 40: 47$ ) was supplied to the working-electrode side and a gaseous mixture of $\mathrm{H}_{2}$ and $\mathrm{H}_{2} \mathrm{O}\left(\mathrm{H}_{2}: \mathrm{H}_{2} \mathrm{O}=53: 47\right)$ was supplied to the counterelectrode side. Humidification was necessary to inhibit the dehydration of $\mathrm{CsH}_{2} \mathrm{PO}_{4}$ electrolyte (Otomo et al., 2003). Electrochemical measurements were obtained using a halfcell configuration and a three-electrode system with Autolab PGSTAT 30 that had a frequency response analyzer module, FRA2 (Eco Chemie B. V.). The potential value reported in this study are with respect to the reversible hydrogen electrode (RHE) and they were $i R$ corrected. The electrolyte resistance was evaluated by ac impedance spectroscopic measurements at $1 \mathrm{kHz}$.

The reaction products of ethanol electro-oxidation under steady-state polarization conditions were captured after vapor-liquid separation with a cold trap. The gaseous and liquid products were then analyzed with a gas chromatograph (GC-8A, Shimadzu Co.) equipped with a thermal conductivity detector (TCD) and a gas chromatograph (GC14B, Shimadzu Co.) equipped with a flame ionization detector (FID), respectively.

\section{Results}

\subsection{Characterization of $\mathrm{PdRu} / \mathrm{C}$ catalyst}

Figure 1 shows the $\mathrm{XRD}$ patterns of the $\mathrm{PdRu} / \mathrm{C}$ samples before and after heat treatment at $350^{\circ} \mathrm{C}$ in $\mathrm{H}_{2} / \mathrm{Ar}$. Diffraction peaks at around $40^{\circ}, 68^{\circ}$, and $82^{\circ}$ correspond to the diffraction at $\operatorname{Pd}(111), \operatorname{Pd}(220)$, and $\operatorname{Pd}(311)$ planes, respectively. In addition, a broad diffraction peak at around $44^{\circ}$, which is related to the $\mathrm{Ru}(101)$ planes, was observed in the $\mathrm{PdRu} / \mathrm{C}$ sample after the heat treatment. Each diffraction peak agreed with the Joint Committee for Powder Diffraction Standards (JCPDS) data and no peak shift was observed. These results suggest that most of $\mathrm{Pd}$ and $\mathrm{Ru}$ exist in separate phases, which agrees with the previous reports of $a b$ initio calculations and experiments (Curtarolo et al., 2005; Fisher et al., 2009). The crystallite size of the Pd nanoparticles was $5 \mathrm{~nm}$ after the heat treatment, which was calculated from the diffraction peak of $\operatorname{Pd}(220)$ using the Scherrer formula.

Figure 2 shows the TEM image of $\mathrm{PdRu} / \mathrm{C}$ after the heat treatment at $350^{\circ} \mathrm{C}$. It can be seen that the nanoparticles 


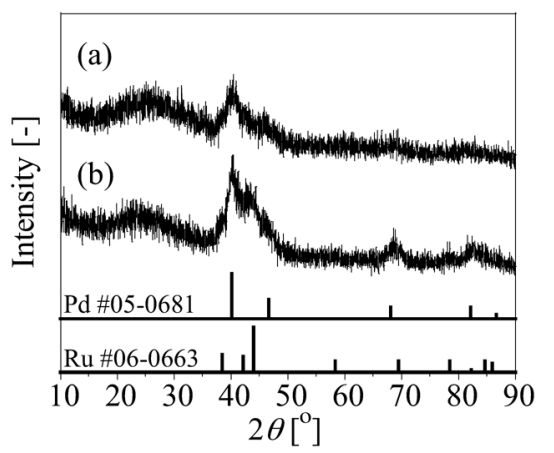

Fig. 1 XRD patterns of the prepared $\mathrm{PdRu} / \mathrm{C}$ catalyst (a) before and (b) after the annealing in $1 \% \mathrm{H}_{2} / 99 \% \mathrm{Ar}$ atmosphere at $350^{\circ} \mathrm{C}$

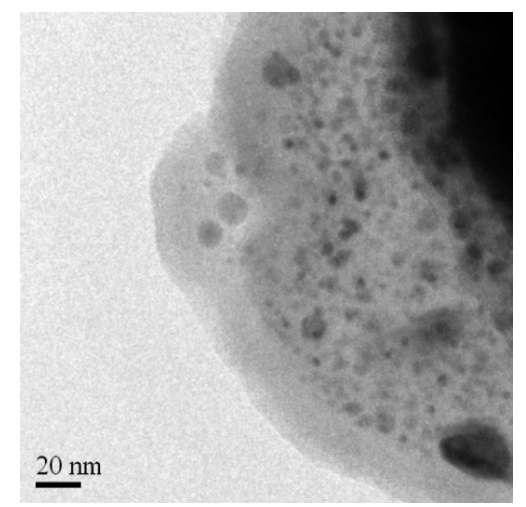

Fig. 2 TEM micrograph of the prepared $\mathrm{PdRu} / \mathrm{C}$ catalyst after annealing in $1 \% \mathrm{H}_{2} / 99 \% \mathrm{Ar}$ atmosphere at $350^{\circ} \mathrm{C}$

are fully dispersed on the carbon support. The size of the nanoparticles ranges from 3 to $20 \mathrm{~nm}$. Considering the peak width of the diffraction pattern shown in Figure 1, Pd may constitute the relatively larger particles and Ru may constitute the relatively smaller particles.

\subsection{Electrochemical measurement and reaction products analysis of ethanol electro-oxidation}

Figure 3(a) shows the current density of ethanol electrooxidation on $\mathrm{PdRu} / \mathrm{C}$ at $250^{\circ} \mathrm{C}$. The onset potential was ca. $130 \mathrm{mV}$, which is close to the value observed with ethanol electro-oxidation on $\mathrm{Pt} / \mathrm{C}$ at $250^{\circ} \mathrm{C}$ (ca. $120 \mathrm{mV}$ ) (Shimada et al., 2011). The oxidation current rose sharply in the potential range $130-300 \mathrm{mV}$, and it gradually increased at the potential higher than $300 \mathrm{mV}$. These low onset potential and high activity values in the lower-potential region indicate a small activation overpotential in the operation of DEFC.

Figure $3(\mathbf{b})$ shows the concentration of the reaction products at $250^{\circ} \mathrm{C}$. The main reaction products on $\mathrm{PdRu} / \mathrm{C}$ were $\mathrm{H}_{2}, \mathrm{CO}_{2}$, and $\mathrm{CH}_{4}$, while small amounts of $\mathrm{CO}, \mathrm{CH}_{3} \mathrm{CHO}$, and $\mathrm{CH}_{3} \mathrm{COOH}$ were also observed. The formation of $\mathrm{C}_{1}$ species as the main reaction products suggests that the $\mathrm{C}-\mathrm{C}$ bond dissociation reaction proceeds rapidly. The carbonbased selectivity, $S_{\mathrm{X}}$, and C-C bond dissociation ratio, $S_{\mathrm{C}-\mathrm{C}}$, were calculated with Eqs. (1) and (2), respectively, and are shown in Figure 4.

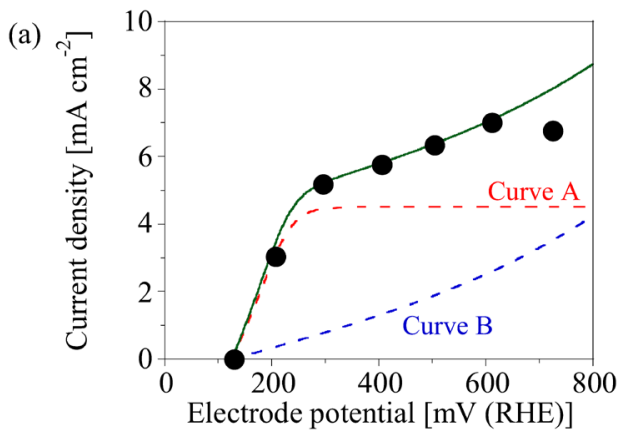

(b)

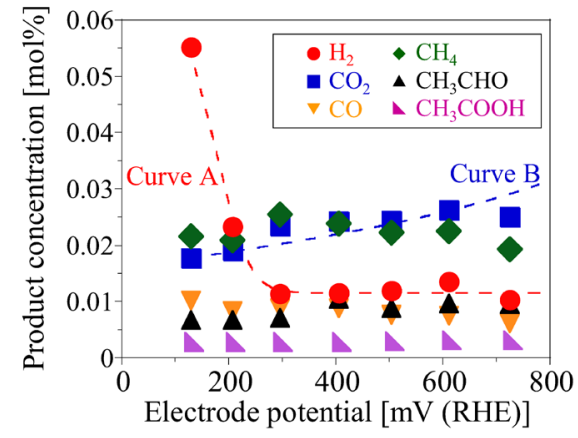

Fig. 3 (a) Steady-state polarization curves of ethanol electrooxidation on the $\mathrm{PdRu} / \mathrm{C}$ catalyst at $250^{\circ} \mathrm{C}(i R$-corrected). Ethanol $(13 \mathrm{~mol} \%) /$ water $(40 \mathrm{~mol} \%) / \mathrm{Ar}(47 \mathrm{~mol} \%)$; total flow rate: $45 \mathrm{~mL} \mathrm{~min}^{-1}$ (sccm). Filled symbol: experimental data; broken lines (curves $\mathrm{A}$ and $\mathrm{B}$ ): predictions for the current density of the direct route $\left(i_{\mathrm{A}}\right)$ and the indirect route $\left(i_{\mathrm{B}}\right)$ (see text); solid line: summations of $i_{\mathrm{A}}$ and $i_{\mathrm{B}}\left(i_{\text {total }}\right)$. (b) Concentration of reaction products corresponding to the current density. Symbols: experimental data; broken lines: predictions for concentrations of $\mathrm{H}_{2}$ (curve $\mathrm{A}$ ) and $\mathrm{CO}_{2}$ (curve $\mathrm{B}$ )

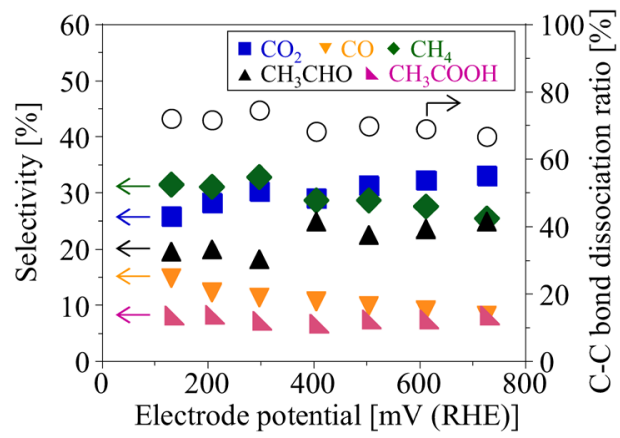

Fig. 4 Selectivity of reaction products and $\mathrm{C}-\mathrm{C}$ bond dissociation ratio in ethanol electro-oxidation on the $\mathrm{PdRu} / \mathrm{C}$ catalyst at $250^{\circ} \mathrm{C}$. Filled symbols: product selectivity; open circles: C-C bond dissociation ratio

$$
\begin{aligned}
& S_{\mathrm{X}}=\frac{n_{\mathrm{X}} C_{\mathrm{X}}}{C_{\mathrm{CO}_{2}}+C_{\mathrm{CO}}+C_{\mathrm{CH}_{4}}+2 C_{\mathrm{CH}_{3} \mathrm{CHO}}+2 C_{\mathrm{CH}_{3} \mathrm{COOH}}} \\
& S_{\mathrm{C}-\mathrm{C}}=S_{\mathrm{CO}_{2}}+S_{\mathrm{CO}}+S_{\mathrm{CH}_{4}}
\end{aligned}
$$

As shown in Figure 4, approximately $70 \%$ of the $\mathrm{C}-\mathrm{C}$ bond of ethanol dissociated on PdRu/C. This ratio is similar to the value for ethanol electro-oxidation on $\mathrm{PtRu} / \mathrm{C}$ at the inter- 
mediate temperature (Shimada et al., 2013) and much higher than the value for ethanol electro-oxidation on $\mathrm{PtRu} / \mathrm{C}$ at a low temperature (Wang et al., 2006b).

\subsection{Parallel reaction model}

It can be seen in Figure 3 that $\mathrm{CO}_{2}$ concentration increased gradually with increasing electrode potential and it followed the increase in current density at potentials higher than $300 \mathrm{mV}$. This result suggests that the electrochemical total oxidation of ethanol (Eq. (3)) proceed on PdRu/C.

$$
\mathrm{CH}_{3} \mathrm{CH}_{2} \mathrm{OH}+3 \mathrm{H}_{2} \mathrm{O} \rightarrow 2 \mathrm{CO}_{2}+12 \mathrm{H}^{+}+12 \mathrm{e}^{-}
$$

In addition, high concentration of $\mathrm{H}_{2}$ was observed at rest potential and it decreased drastically with an increase in the potential from 130 to $300 \mathrm{mV}$, which corresponds to the potential range with a sharp increase in current density. A similar result was observed in our previous study on a $\mathrm{Pt} / \mathrm{C}$ catalyst (Shimada et al., 2011), and it suggests that $\mathrm{H}_{2}$ production via thermal decomposition of ethanol (Eq. (4)) and subsequent electro-oxidation of $\mathrm{H}_{2}$ (Eq. (5)) proceed on $\mathrm{PdRu} / \mathrm{C}$ at the intermediate temperature.

$$
\begin{aligned}
& \mathrm{CH}_{3} \mathrm{CH}_{2} \mathrm{OH} \rightarrow n \mathrm{H}_{2}+\text { carbon species } \\
& \mathrm{H}_{2} \rightarrow 2 \mathrm{H}^{+}+2 \mathrm{e}^{-}
\end{aligned}
$$

These observations suggest that the direct electro-oxidation of ethanol (direct route, route $\mathrm{A}$ ) and $\mathrm{H}_{2}$ production and subsequent electro-oxidation (indirect route, route $\mathrm{B}$ ) proceed in parallel on $\mathrm{PdRu} / \mathrm{C}$ at the intermediate temperature. To investigate the contribution of each reaction route to the total reaction, a simple model for the parallel reactions was developed and the polarization curve and reaction products were analyzed by the model, as shown in Figure 3. The details of the parallel reaction model is described in our previous paper (Otomo et al., 2008a). The Butler-Volmer formulation, Eq. (6), was adopted for the relationship between the current density and the activation overpotential of the direct route. Assuming that a transfer coefficient, $\alpha$, is equal to 0.5 , Eq. (7) was obtained.

$$
\begin{aligned}
& i_{\mathrm{A}}=i_{0}\left(\exp \left(\frac{(1-\alpha) n F \eta_{\mathrm{act}, \mathrm{A}}}{R T}\right)-\exp \left(-\frac{\alpha n F \eta_{\mathrm{act}, \mathrm{A}}}{R T}\right)\right) \\
& \eta_{\mathrm{act}, \mathrm{A}}=\frac{R T}{\beta F} \sinh ^{-1}\left(\frac{i_{\mathrm{A}}}{2 i_{0, \mathrm{~A}}}\right)
\end{aligned}
$$

Similarly, the activation overpotential of the indirect route $(n=2)$ was represented as Eq. (8).

$$
\eta_{\mathrm{act}, \mathrm{B}}=\frac{R T}{F} \sinh ^{-1}\left(\frac{i_{\mathrm{B}}}{2 i_{0, \mathrm{~B}}}\right)
$$

As shown in Figure 3(b), the $\mathrm{H}_{2}$ concentration remains constant at potentials higher than $300 \mathrm{mV}$, which suggests that the rate of the indirect route is dominated by a mass-transfer process at the higher-potential region. Therefore, a concentration overpotential should be considered for the indirect route in addition to the activation overpotential, which is represented as follows.

$$
\eta_{\text {conc, } \mathrm{B}}=\frac{R T}{2 F} \ln \left(1-\frac{i_{\mathrm{B}}}{i_{\mathrm{lim}, \mathrm{B}}}\right)
$$

The limiting current density of the indirect route, $i_{\text {lim, }, \mathrm{B}}$, was obtained by fitting Eq. (10) to the $\mathrm{H}_{2}$ concentration at potentials higher than $300 \mathrm{mV}$, as shown in Figure 3(b).

$$
C_{\mathrm{H}_{2}}=\left(r_{\mathrm{H}_{2}} \rho_{\text {metal }}-\frac{i_{\text {lim }, \mathrm{B}}}{2 F}\right) \frac{A_{\text {electrode }}}{V_{\text {out }}} \times 100
$$

The concentration overpotential of the direct route will be negligible because the concentration of ethanol is adequately high in comparison with $\mathrm{H}_{2}$. Thus, the following parallel circuit model was developed and fitted to the current density shown in Figure 3(a).

$$
\begin{aligned}
& \eta_{\text {total }}=\eta_{\text {act, } \mathrm{A}}=\eta_{\text {act }, \mathrm{B}}+\eta_{\text {conc }, \mathrm{B}} \\
& i_{\text {total }}=i_{\mathrm{A}}+i_{\mathrm{B}}
\end{aligned}
$$

The current density and concentration of $\mathrm{H}_{2}$ and $\mathrm{CO}_{2}$ predicted from the parallel reaction model are plotted in Figure 3. The fitting parameters are summarized in Table 1. As shown in Figure 3, the proposed model well reproduces the dependence of the current density and concentrations of $\mathrm{H}_{2}$ and $\mathrm{CO}_{2}$ on the electrode potential.

The reaction parameters of ethanol electro-oxidation on $\mathrm{PdRu} / \mathrm{C}$ were compared with those on $\mathrm{PtRu} / \mathrm{C}$, which we have reported in the previous study (Shimada et al., 2013). Assuming the same parallel reaction model described above, the reaction parameters on $\mathrm{PtRu} / \mathrm{C}$ were obtained and they are summarized in Table 1 . It can be seen that the exchange current density of the indirect route, $i_{0, \mathrm{~B}}$, on $\mathrm{PdRu} / \mathrm{C}$ is comparable to that on $\mathrm{PtRu} / \mathrm{C}$. Moreover, the $\mathrm{H}_{2}$-production rate per mass of the catalyst at the onset potential, $r_{\mathrm{H}_{2}}$, on $\mathrm{PdRu} / \mathrm{C}$ is higher than that on $\mathrm{PtRu} / \mathrm{C}$. These results suggest that the catalytic activity of $\mathrm{PdRu} / \mathrm{C}$ for the indirect route,

Table 1 Comparison of the reaction parameters of ethanol electrooxidation at $250^{\circ} \mathrm{C}$ between the $\mathrm{PdRu} / \mathrm{C}$ and $\mathrm{PtRu} / \mathrm{C}$ catalysts (Shimada et al., 2013)

\begin{tabular}{lcc}
\hline Catalyst & PdRu/C & PtRu/C \\
\hline Composition & Pd: $20 \mathrm{wt} \%$ & Pt: $30.2 \mathrm{wt} \%$ \\
& Ru: $20 \mathrm{wt} \%$ & Ru: $23.5 \mathrm{wt} \%$ \\
& Separate phase & Alloy \\
Particle size $[\mathrm{nm}]$ & $3-20$ & 5 \\
$\rho_{\text {metal }}\left[\mathrm{mg} \mathrm{cm}^{-2}\right]$ & 2.0 & 3.6 \\
$r_{\mathrm{H}_{2}}\left[\mathrm{~mol} \mathrm{~g} \mathrm{metal}^{-1} \mathrm{~s}^{-1}\right]$ & $1.5 \times 10^{-5}$ & $9.1 \times 10^{-6}$ \\
$i_{0, \mathrm{~A}}\left[\mathrm{~mA} \mathrm{~cm}^{-2}\right]$ & 1.0 & 3.5 \\
$i_{0, \mathrm{~B}}\left[\mathrm{~mA} \mathrm{~cm}^{-2}\right]$ & 1.0 & 1.2 \\
$i_{\text {lim, } \mathrm{B}}\left[\mathrm{mA} \mathrm{cm}^{-2}\right]$ & 4.5 & 5.3 \\
$\beta[-]$ & 0.10 & 0.17 \\
\hline
\end{tabular}


i.e., $\mathrm{H}_{2}$ production and subsequent $\mathrm{H}_{2}$ electro-oxidation, is the same or higher than that of $\mathrm{PtRu} / \mathrm{C}$. On the other hand, the exchange current density of the direct route, $i_{0, \mathrm{~A}}$, on $\mathrm{PdRu} / \mathrm{C}$ is no more than $30 \%$ of that on $\mathrm{PtRu} / \mathrm{C}$. This suggests that the catalytic activity of $\mathrm{PdRu} / \mathrm{C}$ for the direct route, i.e., the electrochemical total oxidation of ethanol, is inferior to that of $\mathrm{PtRu} / \mathrm{C}$, which results in the difference of $\mathrm{CO}_{2}$ selectivity at high electrode potentials (e.g., $32 \%$ and $58 \%$ on $\mathrm{PdRu} / \mathrm{C}$ and $\mathrm{PtRu} / \mathrm{C}$, respectively, at ca. $600 \mathrm{mV}$ ).

\section{Discussion}

In the previous studies, we proposed the detailed reaction mechanism of ethanol electro-oxidation on Pt-based catalysts at the intermediate temperature (Shimada et al., 2011, 2013). In this section, we discuss the reaction mechanism of ethanol electro-oxidation on the $\mathrm{PdRu} / \mathrm{C}$ catalyst at the intermediate temperature in comparison with those on the Pt-based catalysts.

Figure 5 shows the reaction mechanism of ethanol electro-oxidation on the $\mathrm{Pt} / \mathrm{C}$ and $\mathrm{PtRu} / \mathrm{C}$ catalysts at the intermediate temperature. Initially, ethanol adsorbs onto the $\mathrm{Pt}$ surface and the dehydrogenation reaction proceeds to form $\mathrm{CH}_{x} \mathrm{CO}^{*}$ and $\mathrm{H}^{*}$ (R1). Different from the reaction at low temperature, the $\mathrm{C}-\mathrm{C}$ bond dissociation reaction ( $\mathrm{R} 4)$ proceeds rapidly at the intermediate temperature and the main adsorbates on the Pt surface are $\mathrm{C}_{1}$ species such as $\mathrm{CH}_{x}{ }^{*}$ and CO*. These adsorbates desorb into the gas phase as $\mathrm{CH}_{4}$ and $\mathrm{CO}$, or they are oxidized with $\mathrm{OH}^{*}$ to produce $\mathrm{CO}_{2}$. An effect of $\mathrm{Ru}$ addition is to promote the $\mathrm{OH}^{*}$ formation reaction ( $\mathrm{R} 10)$, which results in the acceleration of oxidation of $\mathrm{C}_{1}$ adsorbates on Pt. On the other hand, we observed that the rapid $\mathrm{C}-\mathrm{C}$ bond dissociation proceeds and the main reaction products are $\mathrm{C}_{1}$ species such as $\mathrm{CO}_{2}$ and $\mathrm{CH}_{4}$ in the ethanol electro-oxidation on $\mathrm{PdRu} / \mathrm{C}$ at the intermediate temperature. This indicates that the reaction mechanism of ethanol oxidation on $\mathrm{PdRu} / \mathrm{C}$ is similar to that on the $\mathrm{Pt}$-based catalyst. Because the $\mathrm{PdRu} / \mathrm{C}$ catalyst prepared in this study consists of the separate phases of $\mathrm{Pd}$ and $\mathrm{Ru}$, it is

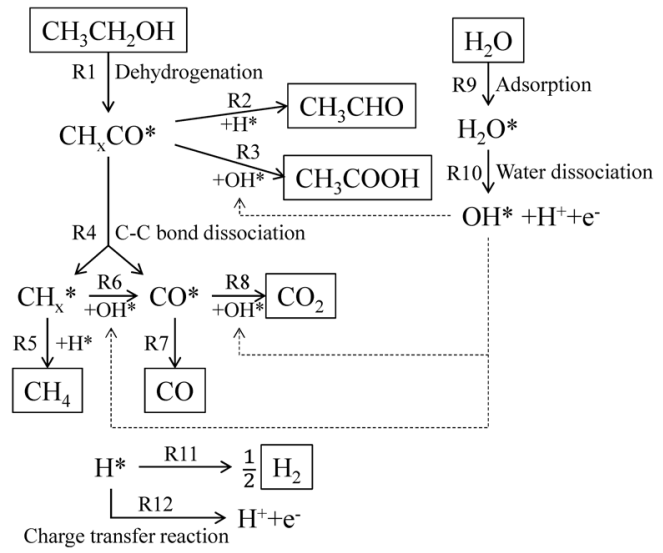

Fig. 5 Schematic representation of proposed reaction mechanisms for ethanol electro-oxidation at approximately $250^{\circ} \mathrm{C}$ expected that the reaction pathway, which is similar to that shown in Figure 5, proceeds on the Pd surface at the intermediate temperature.

In the reaction pathways shown in Figure 5, there are three branches that determine the reaction product distribution, which correspond to the reactions of adsorbates $\mathrm{CH}_{x} \mathrm{CO}^{*}, \mathrm{CH}_{x}{ }^{*}$, and $\mathrm{CO}^{*}$. The branching ratios of each branch were defined by the following equations denoted as $B r_{\mathrm{I}}, B r_{\mathrm{II}}$, and $B r_{\mathrm{III}}$, respectively, and calculated on the basis of the reaction product concentration.

$$
\begin{aligned}
& B r_{\mathrm{I}}=\frac{r_{\mathrm{R} 4}}{r_{\mathrm{R} 2}+r_{\mathrm{R} 3}+r_{\mathrm{R} 4}} \times 100 \\
& B r_{\mathrm{II}}=\frac{r_{\mathrm{R} 6}}{r_{\mathrm{R} 5}+r_{\mathrm{R} 6}} \times 100 \\
& B r_{\mathrm{III}}=\frac{r_{\mathrm{R} 8}}{r_{\mathrm{R} 7}+r_{\mathrm{R} 8}} \times 100
\end{aligned}
$$

All the branching ratios are equal to $100 \%$ if the total oxidation of ethanol. The branching ratios on $\mathrm{PdRu} / \mathrm{C}$ and $\mathrm{PtRu} / \mathrm{C}$ are compared in Figure 6. On $\mathrm{PdRu} / \mathrm{C}, B r_{\mathrm{I}}$ was comparable to that on $\mathrm{PtRu} / \mathrm{C}$, while $B r_{\mathrm{II}}$ and $B r_{\mathrm{III}}$ fell below those on PtRu/C. In addition, $B r_{\text {II }}$ and $B r_{\text {III }}$ on PtRu/C drastically increased with an increase in the electrode potential, while the increases of those on $\mathrm{PdRu} / \mathrm{C}$ were limited. Here, $B r_{\text {II }}$ and $B r_{\text {III }}$ are related to reactions R6 and R8, respectively, both of which are the oxidation reactions of $\mathrm{C}_{1}$ adsorbates by $\mathrm{OH}^{*}$, as shown in Figure 5. The reason of the increases of $B r_{\text {II }}$ and $B r_{\text {III }}$ with an increase in the electrode potential is that the $\mathrm{OH}^{*}$ formation reaction (R10) is a charge-transfer reaction, and more $\mathrm{OH}^{*}$ are produced at high electrode potentials. However, the limited increases of $B r_{I I}$ and $B r_{I I I}$ on $\mathrm{PdRu} / \mathrm{C}$ with an increase in the electrode potential suggest that the reaction activity of $\mathrm{OH}^{*}$ was not very high and the oxidation of the adsorbed $\mathrm{C}_{1}$ species may be the rate-determining step on $\mathrm{PdRu} / \mathrm{C}$. Indeed, in the literature, the DFT calculations point out that a reaction barrier of water dissociation on $\mathrm{Pd}$ is higher than that on $\mathrm{Pt}$ or $\mathrm{Ru}$, and the surface coverage of $\mathrm{OH}$ adsorbate on $\mathrm{Pd}$ is quite small (Wang

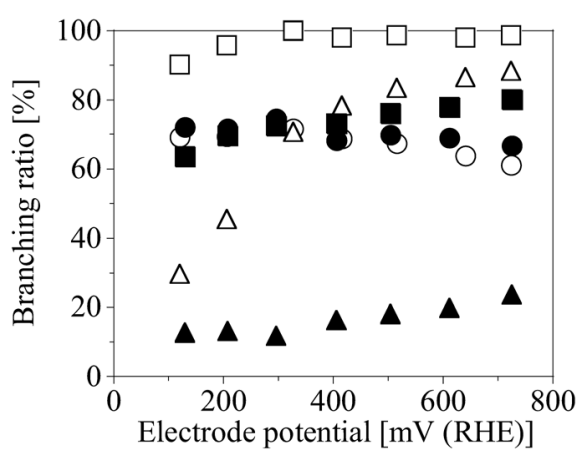

Fig. 6 Branching ratios of ethanol electro-oxidation on $\mathrm{PdRu} / \mathrm{C}$ and $\mathrm{PtRu} / \mathrm{C}$ at $250^{\circ} \mathrm{C}$. Filled symbols: branching ratios on $\mathrm{PdRu} / \mathrm{C}$; open symbols: branching ratios on PtRu/C. Circles: $B r_{\mathrm{I}}$; triangles: $B r_{\text {II }}$; squares: $B r_{\text {III }}$ 
et al., 2006a; Phatak et al., 2009; Zeinalipour-Yazdi and van Santen, 2009). There is another reason for the poor reaction activity of $\mathrm{PdRu} / \mathrm{C}$ on $\mathrm{OH}^{*}$ formation reaction even at high electrode potential, i.e., surface diffusion of $\mathrm{OH}^{*}$ formed on the $\mathrm{Ru}$ surface site to the Pd surface site may be limited so that the oxidation of the $\mathrm{C}_{1}$ adsorbates on $\mathrm{Pd}$ with $\mathrm{OH}^{*}$ does not proceed well. This may be because the catalytic sites of Pd and $\mathrm{Ru}$ were not close enough because the prepared $\mathrm{PdRu} / \mathrm{C}$ catalyst consists of the separate phases of $\mathrm{Pd}$ and $\mathrm{Ru}$. Considering the above, further activation of $\mathrm{OH}^{*}$ on the catalyst surface would be required to improve the $\mathrm{CO}_{2}$ selectivity in ethanol electro-oxidation. For this purpose, it is indispensable to develop electrode catalysts that promote water adsorption and dissociation reactions (e.g., composite materials with metal oxides), as well as the preparation of fine Pd nanoparticles that are well dispersed on the catalyst support so that the $\mathrm{OH}^{*}$ species formed on the composite materials such as $\mathrm{Ru}$ or metal oxides can diffuse to the Pd site and oxidize the adsorbates on Pd. These are the subjects of our future work.

\section{Conclusion}

In this study, a $\mathrm{PdRu} / \mathrm{C}$ catalyst was synthesized by a liquid phase reduction method and its catalytic activity for ethanol electro-oxidation at the intermediate temperature $\left(250^{\circ} \mathrm{C}\right)$ was investigated by electrochemical measurements and reaction product analysis. The characteristic features of the electro-oxidation of ethanol on the $\mathrm{PdRu} / \mathrm{C}$ catalyst at the intermediate temperature are described below. (1) The onset potential of ethanol electro-oxidation on the $\mathrm{PdRu} / \mathrm{C}$ catalyst was comparable to that on the $\mathrm{Pt} / \mathrm{C}$ and $\mathrm{PtRu} / \mathrm{C}$ catalysts, which indicates small activation overpotentials of DEFCs. (2) Direct electro-oxidation of ethanol (direct route) and $\mathrm{H}_{2}$ production via thermal decomposition of ethanol and the subsequent $\mathrm{H}_{2}$ electro-oxidation (indirect route) proceed in parallel. The catalytic activity of the indirect route on the $\mathrm{PdRu} / \mathrm{C}$ catalyst was comparable to that on the $\mathrm{PtRu} / \mathrm{C}$ catalyst, and the indirect route accounts for a large fraction of the total oxidation current on the $\mathrm{PdRu} / \mathrm{C}$ catalyst. (3) Rapid C-C bond dissociation proceeds on the $\mathrm{PdRu} / \mathrm{C}$ catalyst, while the subsequent oxidation of the adsorbed $\mathrm{C}_{1}$ species may be the rate-determining step. These observations suggest the possibility for an efficient use of ethanol fuel on the $\mathrm{PdRu} / \mathrm{C}$ catalyst at the intermediate temperature. On the other hand, suppression of the by-product formation and acceleration of the total oxidation reaction of ethanol remain a challenge. Further development of an electrode catalyst promoting water adsorption and dissociation should be investigated in the future work.

\section{Acknowledgements}

The authors greatly appreciate the efforts of Dr. Daisuke Hamane of the Institute for Solid State Physics at The University of Tokyo, who assisted with the XRD and the TEM measurements. We also thank the Materials Design and Characterization Laboratory, the Institute for
Solid State Physics, The University of Tokyo for the facilities.

This work was financially supported by a Jiro Kondo Grant from the Asahi Glass Foundation, a Grant-in-Aid for Young Scientists (A), No. 20681007, from the Ministry of Education, Culture, Sports, Science, and Technology of Japan and a Grant-in-Aid for JSPS Fellows, No. 23-6233, from the Japan Society for the Promotion of Science, which are greatly appreciated.

\section{Nomenclature}

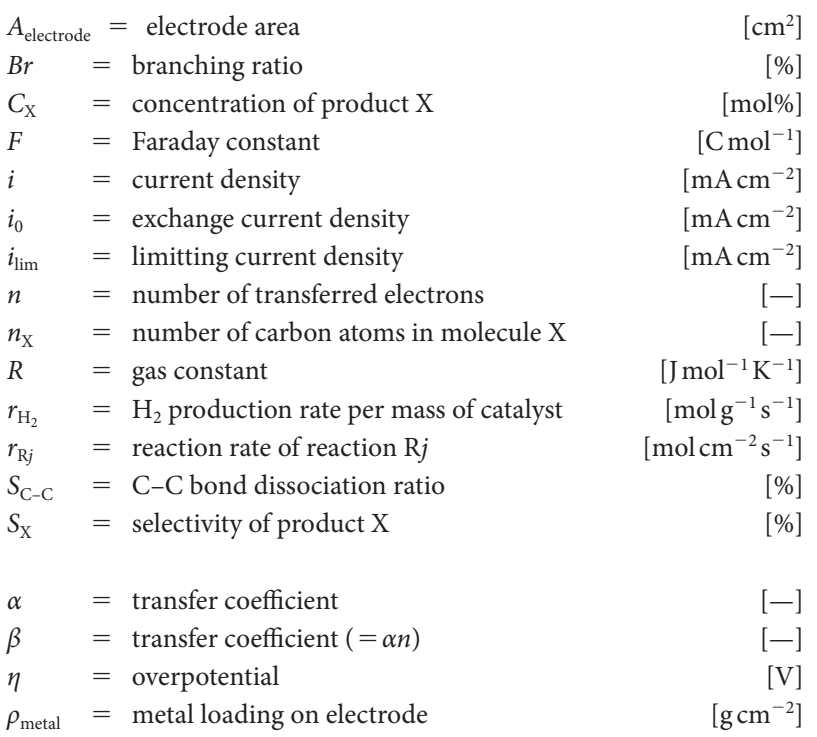

〈Subscripts〉

A $=$ direct route of ethanol electro-oxidation

act = activation overpotential

$\mathrm{B}=$ indirect route of ethanol electro-oxidation

conc $=$ concentration overpotential

total $=$ total overpotential or total current density

\section{Literature Cited}

Cheng, N., H. Lv, W. Wang, S. Mu, M. Pan and F. Marken; "An Ambient Aqueous Synthesis for Highly Dispersed and Active Pd/C Catalyst for Formic Acid Electro-Oxidation," J. Power Sources, 195, 7246-7249 (2010)

Curtarolo, S., D. Morgan and G. Ceder; "Accuracy of $a b$ initio Methods in Predicting the Crystal Structures of Metals: A Review of $80 \mathrm{Bi}$ nary Alloys," Calphad, 29, 163-211 (2005)

Ferrin, P., D. Simonetti, S. Kandoi, E. Kunkes, J. A. Dumesic, J. K. Nørskov and M. Mavrikakis; "Modeling Ethanol Decomposition on Transition Metals: A Combined Application of Scaling and Bronsted-Evans-Polanyi Relations," J. Am. Chem. Soc., 131, 5809-5815 (2009)

Fisher, J. M., N. Cabello-Moreno, E. Christian and D. Thompsett; "Methanol Oxidation Activity of Pdru Alloy Nanoparticles in Direct Methanol Fuel Cells," Electrochem. Solid-State Lett., 12, B77-B81 (2009)

Lamy, C., E. M. Belgsir and J. M. L'eger; "Electrocatalytic Oxidation of Aliphatic Alcohols: Application to the Direct Alcohol Fuel Cell (DAFC)," J. Appl. Electrochem., 31, 799-809 (2001)

Nørskov, J. K., T. Bligaard, A. Logadottir, J. R. Kitchin, J. G. Chen, S. Pandelov and U. Stimming; "Trends in the Exchange Current for Hydrogen Evolution," J. Electrochem. Soc., 152, J23-J26 (2005)

Otomo, J., N. Minagawa, C.-J. Wen, K. Eguchi and H. Takahashi; 
"Protonic Conduction of $\mathrm{CsH}_{2} \mathrm{PO}_{4}$ and Its Composite with Silica in Dry and Humid Atmospheres," Solid State Ion., 156, 357-369 (2003)

Otomo, J., S. Nishida, H. Kato, H. Nagamoto and Y. Oshima; "Direct Alcohol Electro-Oxidation in an Intermediate Temperature Fuel Cell," ECS Trans., 16, 1275-1284 (2008a)

Otomo, J., S. Nishida, H. Takahashi and H. Nagamoto; "Electro-Oxidation of Methanol and Ethanol on Carbon-Supported Pt Catalyst at Intermediate Temperature," J. Electroanal. Chem., 615, 84-90 (2008b)

Phatak, A. A., W. N. Delgass, F. H. Ribeiro and W. F. Schneider; "Density Functional Theory Comparison of Water Dissociation Steps on Cu, Au, Ni, Pd, and Pt," J. Phys. Chem. C, 113, 7269-7276 (2009)

Shigeoka, H., J. Otomo, C.-J. Wen, M. Ogura and H. Takahashi; "Protonic Conduction and Impedance Analysis in $\mathrm{CsHSO}_{4} / \mathrm{SiO}_{2} \mathrm{Com}$ posite Systems," J. Electrochem. Soc., 151, J76-J83 (2004)

Shimada, I., Y. Oshima and J. Otomo; "Acceleration of Ethanol ElectroOxidation on a Carbon-Supported Platinum Catalyst at Intermedi- ate Temperatures," J. Electrochem. Soc., 158, B369-B375 (2011)

Shimada, I., Y. Oshima and J. Otomo; "Ethanol Electro-Oxidation on a PtRu/C Catalyst at Intermediate Temperature: Reaction Kinetic Study on the Effect of Ru Addition," Kagaku Kogaku Ronbunshu, 39, 150-156 (2013)

Wang, G.-C., S.-X. Tao and X.-H. Bu; "A Systematic Theoretical Study of Water Dissociation on Clean and Oxygen-Preadsorbed Transition Metals," J. Catal., 244, 10-16 (2006a)

Wang, H., Z. Jusys and R. J. Behm; "Ethanol Electro-Oxidation on Carbon-Supported Pt, PtRu and $\mathrm{Pt}_{3} \mathrm{Sn}$ Catalysts: A Quantitative DEMS Study," J. Power Sources, 154, 351-359 (2006b)

Watanabe, M. and S. Motoo; "Electrocatalysis by Ad-Atoms: Part II. Enhancement of the Oxidation of Methanol on Platinum by $\mathrm{Ru}$ thenium Ad-Atoms," J. Electroanal. Chem., 60, 267-273 (1975)

Zeinalipour-Yazdi, C. D. and R. A. van Santen; "Kinetic Rates and Linear Free Energy Relationships for Water Dissociation on Transition and Noble Metal Dimers," J. Phys. Chem. A, 113, 6971-6978 (2009) 